\title{
PENGARUH EFEKTIVITAS IKLAN PESAING, ATRIBUT PRODUK, DAN PERILAKU MENCARI VARIASI TERHADAP PERILAKU PERPINDAHAN MEREK PRODUK INDOMIE
}

\author{
Oleh: \\ Samsul Hidayatullah ${ }^{1)}$ \\ Dwiwiyati Astogini ${ }^{2)}$ \\ Sumarsono $^{3}$ ) \\ E-mail: samsul.hide@gmail.com \\ 2) 3) Fakultas Ekonomi dan Bisnis, Universitas Jenderal Soedirman
}

\begin{abstract}
The research entitled "effect of competitor advertisement effectiveness, product attribute, and variety seeking behavior to brand switching behavior of Indomie. The aim of this research is to analyze the effect of competitor advertisement effectiveness, product attribute, and variety seeking behavior to brand switching behavior of Indomie to other brand. Data collection method use questionnaire with a sample 100 respondents from economics and business faculty of Jenderal Soedirman university students who have switched from Indomie to other instant noodle brand. The data is analyzed by using multiple linier regression, meanwhile the significance level use partial test ( $t$ test).

The result shows that competitor advertisement effectiveness, product attribute, and variety seeking behavior have positive significant effect to brand switching behavior of Indomie. Based on this research, managers are recommended to increase the advertising frequency, increase the quality of product, do endorsement, expand the taste variety, and also give innovation to every detail of product or pricing in order to minimalize brand switching behavior of consumer.
\end{abstract}

Keywords: effect of competitor advertisement effectiveness, product attribute, variety seeking behavior, and brand switching behavior. 


\section{PENDAHULUAN}

Krisis keuangan global yang menghantam hampir semua sektor industri termasuk industri makanan, industri mie instan juga terkena imbasnya. Ditambah lagi pada 2008 lalu terjadi kenaikan harga bahan baku utama yaitu tepung terigu akibat penyesuaian terhadap kenaikan harga bahan bakar.

Kenaikan harga komoditas di pasar internasional mengakibatkan inflasi yang tinggi dan melemahnya daya beli masyaraka, sehingga mempengaruhi pertumbuhan industri makanan termasuk industri mie instan yang menurun. Penurunan terjadi terutama pada segmen bawah karena kenaikan harga jual mie instan seiring dengan kenaikan harga tepung terigu sebagai bahan baku utama. Akibatnya sebagian produsen dari mie instan segmen bawah untuk sementara mengurangi berproduksi, karena anjloknya permintaan konsumen dari kalangan ini.

Sedangkan permintaan mie instan dari segmen menengah atas tidak mengalami perubahan. Sehingga industri mie instan segmen menengah atas tetap bersaing ketat. Namun demikian, persaingan di segmen menengah atas tersebut sekarang berlangsung secara lebih sehat. Sebab tidak lagi terjadi perang harga secara terbuka antara dua produsen besar yaitu Grup Indofood dengan Grup Wings, seperti yang terjadi tiga tahun belakangan ini. Semua produsen mie instan segmen menengah atas tersebut serentak menaikkan harga jual produknya menyesuaikan dengan kenaikan biaya produksi yang tinggi.

Data dari Indonesian Comersial Newsletter (ICN) tahun
2009 juga menerangkan bahwa ketatnya persaingan di dalam pasar mie instan, menjadikan penguasaan pasar oleh Grup Indofood melalui PT. Indofood Sukses Makmur dengan merek Indomie berkurang menjadi sekitar $77 \%$ dari sebelumnya $90 \%$. Hal ini terutama disebabkan munculnya pesaing terbesarnya yaitu PT. Prakarsa Alam Segar (Group Wingsfood) dengan produknya Mie Sedaap yang berhasil merebut sebagian pasar Indofood. Wingsfood kini menguasai sekitar $12 \%$ pangsa pasar.

Sejak lima tahun terakhir hingga saat ini praktis pasar mie instan hanya menjadi arena pertarungan antara Indomie (Grup Indofood) dengan Mie Sedaap (Grup Wings), keduanya menguasai sekitar $89 \%$ dari seluruh pasar mie instan di Indonesia. Sementara sejumlah pemain lainnya memperebutkan sisa pangsa pasar yang sangat kecil hanya $11 \%$.

Belakangan ini mie instan merupakan salah satu komoditas yang diikutkan dalam perhitungan garis kemiskinan. Kontribusinya pun cukup besar. Pada September 2014, misalnya, mie instan merupakan salah satu dari lima komoditas makanan yang memberi andil paling besar terhadap garis kemiskinan. Kontribusi mie instan di pedesaan mencapai 2,41 persen, sementara di perkotaan mencapai 2,62 persen.

Data World Instant Noodles Association (WINA) pada tahun 2015 juga memberi konfirmasi bahwa konsumsi mie instan masyarakat Indonesia terus meningkat dari tahun ke tahun. Pada tahun 2013, konsumsi mie instan masyarakat Indonesia sudah mencapai 14,9 miliar bungkus, 
atau mengalami peningkatan sebesar 1 miliar bungkus bila dibandingkan dengan konsumsi pada tahun 2009. Itu artinya, secara rata-rata setiap orang Indonesia mengkonsumsi sekitar 60-61 bungkus atau 1,5 dus mie instan pada tahun 2013. Tingginya angka konsumsi mie instan ini menempatkan Indonesia di posisi kedua sebagai negara pengkonsumsi mie instan terbesar di dunia setelah Cina, yang konsumsinya mencapai 46,2 miliar bungkus.

Kebutuhan konsumsi masyarakat akan mie instan yang meningkat dilihat oleh beberapa perusahaan sebagai peluang mereka meraih konsumen baru. Di sisi lain, banyaknya pesaing baru membuat perusahan-perusahaan lama harus mempertahankan posisi mereka dibenak konsumen. Kondisi tersebut membuat para produsen mulai berkompetisi dengan melakukan diferensiasi. Diferensiasi ini diwujudkan dalam menampilkan atribut produk yang kuat sebagai perwujudan manfaat yang dimiliki oleh produk dengan harapan konsumen akan tertarik pada produk yang dikeluarkan oleh perusahaan.

Dengan beragamnya merek produk mie instan yang ditawarkan kepada konsumen, membuat konsumen memiliki kesempatan untuk beralih dari merek satu ke merek lain dengan mudah. Perpindahan merek di pengaruhi oleh beberapa faktor, yaitu faktor eksternal dan internal. Faktor internal adalah faktor lingkungan dari dalam diri konsumen yang dapat mempengaruhi sikap keputusan pembelian, pemilihan merek serta perpindahan merek baik secara rasional maupun emosional. Yang merupakan dimensi faktor internal konsumen adalah keinginan untuk mencari variasi (variety seeking), ketidakpuasan pasca konsumsi (dissatisfaction). Faktor eksternal adalah faktor lingkungan luar dari diri konsumen yang dapat mempengaruhi perpindahan merek baik itu secara rasional maupun emosional, yang dapat dijelaskan oleh iklan, promosi dalam toko dll. Selain itu bertambah banyaknya perusahaan yang memutuskan untuk memasuki pasar, konsumen akan dihadapkan oleh beragam jenis merek dengan atributatribut produk yang menarik. Dimana Simamora (2007 : 109) menjelaskan hal tersebutakan memicu perilaku pembelian mencari keragaman (variety seeking buying behavior) yang akan bertujuan pada peralihan merek (brand switching).

Salah satu upaya yang dapat dilakukan untuk mempertahankan maupun merebut pangsa pasar baru adalah mengkomunikasikan produk melalui promosi di media iklan. Jika dilihat fungsi dan tujuannya, pada hakikatnya iklan adalah salah satu bentuk komunikasi. Dari sini dapat ditarik benang merah bahwa iklan memiliki fungsi utama menyampaikan informasi tentang produk kepada massa (nonpersonal). Ia menjadi penyampai informasi yang sangat terstruktur, yang menggunakan elemen-elemen verbal. Dalam menjalankan fungsi komunikasinya ini, iklan memiliki berbagai gaya, baik dalam penyajian maupun isi iklan itu sendiri. Pada awalnya, iklan menggunakan pendekatan yang berorientasipada produk yang diiklankan itu sendiri, mulai dari segi fungsi, harga maupun kualitasnya. 
Produk-produk yang biasa dikonsumsi ini tentu akan menimbulkan kejenuhan tersendiri bagi konsumen, sehingga menjadi hal yang wajar bagi mereka untuk mencari variasi untuk produk yang mereka inginkan. Simamora (2007:109) lebih lanjut menjelaskan bahwa konsumen yang memiliki tipe perilaku pembelian mencari variasi seringkali melakukan peralihan merek dan konsumen yang paling mudah dipengaruhi untuk berganti merek adalah mahasiswa. Ketika konsumen suka mencari variasi maka konsumen akan lebih termotivasi untuk berpindah merek, namun ketika mereka tidak suka mencari variasi maka konsumen kurang termotivasi untuk berpindah merek.

Di antara banyaknya merek mie instan yang banyak bermunculan baik dari luar negeri maupun dalam negeri, ada satu merek mie instan yang masih menjadi favorit masyarakatIndonesia dan dianggap sebagai leader brand dalam kategori produk mie instan, yaitu Indomie yang diproduksi oleh PT. Indofood Sukses.

Sayangnya, dengan banyaknya merek mie instan yang hadir di Indonesia membuat konsumen Indomie beralih ke merek lain karena konsumen dapat memperoleh informasi tentang berbagai merek lain dengan berbagai variasi yang ditawarkan dan juga kebutuhan mencari variasi untuk mengonsumsi produk yang sama dari merek lain, meskipun Indomie sudah menawarkan produk dengan berbagai atribut produk yang kuat, seperti rasa yang bervariasi, harga terjangkau, dan kualitas bahan, baik mie, bumbu, dan lain sebagainya. Dan juga menerapkan berbagai cara promosi dengan pengiklanan yang menggunakan berbagai mediayang ada baik itu televisi, media cetak maupun media online.Hal ini diperkuat dengan berbagai data yang ada, yang awalnya indomie dapat menguasai pasar sekitar $90 \%$ namun pangsa pasar mulai diambil oleh berbagai merek baru sehinga merosot hingga $77 \%$.

Dalam hal ini perpindahan merek dapat dengan mudah dilakukan oleh para konsumen. Faktor apa sajakah yang membuat konsumen berpindah merek menjadi pertanyaan peneliti untuk melakukan penelitian terhadap konsumen yang mengkonsumsi mie instan dan perpindahan merek yang mereka lakukan. Konsumen yang diteliti untuk penelitian ini adalah mahasiswa. Hal tersebut didasari dari penelitian Burst Media menyatakan bahwa mahasiswa adalah konsumen yang paling banyak terpengaruh untuk melakukan perpindahan merek.

Berdasarkan uraian permasalahan di atas, peneliti mengembangkan penelitian sebelumnya untuk mengetahui bagaimana efektivitas iklan pesaing, atribut produk dan perilaku mencari variasi mempengaruhi perpindahan merek pada produk Indomie. Karena itulah, dirasakan perlu melakukan penelitian tentang "Pengaruh Efektivitas Iklan Pesaing, Atribut Produk, dan Perilaku Mencari VariasiTerhadap Perpindahan Merek Produk Indomie" (Studi pada Mahasiswa Fakultas Ekonomi dan Bisnis Universitas Jenderal Soedirman).

\section{Permasalahan}

Masalah yang menjadi dasar peneliti adalah turunnya pangsa pasar 
Indomie sekitar 13\%, hal ini mengindikasikan terjadinya perpindahan merek dari Indomie ke merek mie instanlainnya. Perpindahan merek di pengaruhi oleh beberapa faktor, yaitu faktor eksternal dan internal. Yang merupakan faktor eksternal diantaranya adalah efektivitas iklan dan atribut produk, sedangkan yang merupakan faktor eksternal diantaranya perilaku mencari variasi.

Dalam penelitian ini, peneliti berusaha mengetahui efektivitas iklan pesaing, atribut produk, dan perilaku mencari variasi berpengaruh terhadap perilaku perpindahan merek?

\section{Tujuan Penelitian}

Adapun tujuan penelitian yang ingin dicapai adalah:

1. Untuk menganalisis pengaruh efektivitas iklan pesaing terhadap perilaku perpindahan merek.
2. Untuk menganalisis pengaruh atribut produk terhadap perilaku perpindahan merek.

3. Untuk menganalisis pengaruh perilaku mencari variasi terhadap perilaku perpindahan merek.

\section{Variabel dan Pengukuran}

Dalam menganalisis pengaruh Perilaku Perpindahan Merek dari Indomie ke merek mie lain, variabel bebas dalam penelitian ini yaitu Efektivitas iklan pesaing, Atribut produk, dan Perilaku mencari variasi. Pengukuran variabel digunakan skala interval data terhadap pertanyaan dengan interval lima angka yang mewakilinya (Suliyanto, 2011:10): Jawaban Sangat Setuju (skor 5), Setuju (skor 4), Cukup Setuju (skor 3), Tidak Setuju (skor 2), dan Sangat Tidak Setuju ( skor 1)

\section{Model Penelitian}

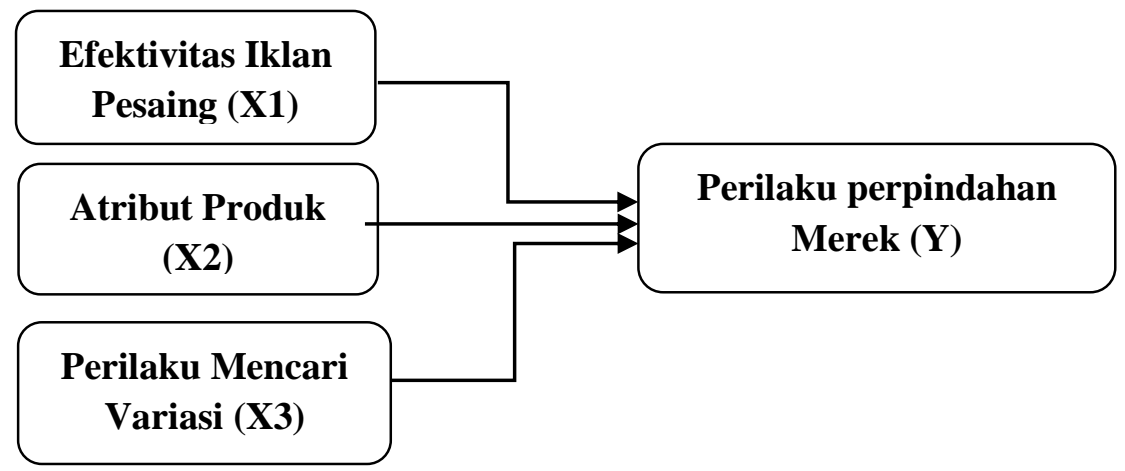

\section{Gambar 1. Model Penelitian}

Hipotesis

H1: Efektivitas iklan pesaing berpengaruh terhadap perilaku perpindahan merek.

H2: Atribut produk berpengaruh terhadap perilaku perpindahan merek.
H3: Perilaku mencari variasi berpengaruh terhadap perilaku perpindahan merek.

\section{METODE ANALISIS}

Populasi dan Teknik Pengambilan Sampel 


\begin{tabular}{lcr}
\multicolumn{1}{c}{ Penelitian } & ini & merupakan \\
penelitian & survey & dengan \\
menggunakan & kuisioner & pada \\
mahasiswa & Fakultas & Ekonomi dan \\
Bisnis & Universitas & Jenderal \\
Soedirman & yang & pernah \\
mengkonsumsi & produk & Indomie.
\end{tabular}

Karena ukuran populasi tidak diketahui, maka untuk menentukan ukuran sampel minimum menggunakan interval taksiran ():

$$
n=\left(\frac{Z^{2} a / 2 x p x q}{e^{2}}\right)
$$

Keterangan:

$\mathrm{n}$ : jumlah sampel minimal

$\mathrm{Z}$ : area bawah kurva normal

E: tingkat kesalahan yang mungkin terjadi

p: proporsi yang diharapkan

q: proposi yang tidak diharapkan

Dengan menggunakan tingkat kepercayaan sebesar 95\%, maka nilai koefisien sebesar 1,96. Tingkat kesalahan ditetapkan 10\%, maka sampel minimum dapat dihitung sebagai berikut:

Dengan mengasumsikan nilai $\mathrm{p}=$ 0,5 dan $\mathrm{q}=0,5$.

$$
n=\left(\frac{1,96^{2} \times 0,5 \times 0,5}{0.10^{2}}\right)=96,04
$$

Berdasarkan metode interval taksiran, jumlah sampel minimum yang harus di ambil sebanyak 96,04. Dari sampel minimal tesebut, maka peneliti menggunakan sampel sebanyak 100 responden.

\section{Definisi Operasional Variabel}

Perilaku Perpindahan Merek

Peralihan dari produk indomie ke produk mie instan lain yang dilakukan oleh konsumen karena faktor tertentu.
Efektivitas Iklan Pesaing

Strategi penerapan iklan yang

dilakukan merek lain untuk

mendapat perhatian konsumen

sehingga timbul keinginan untuk membeli merek lain.

Atribut Produk

Manfaat yang ditawarkan dari produk selain produk indomie yang dijadikan alasan untuk melakukan pembelian.

\section{Perilaku Mencari Variasi}

Sikap konsumen yang cenderung mencari kepuasan dalam mengkonsumsi sebuah produk dan berusaha untuk memenuhi kepuasan dengan melakukan pencarian variasi produk mie instan lain selain produk indomie.

\section{Teknik Analisis Data}

Sebelum menganalisis data, terlebih dahuludilakukan uji validitas dan uji reliabilitas. Uji Validitas didefinisikan sejauh mana ketepatan dan kecermatan suatu alat ukur dalam melakukan fungsi ukurannya (Suliyanto, 2005:40).

Uji validitas pada penelitian ini dilakukan dengan teknik korelasi product moment dengan rumus (Suliyanto, 2011:16):

$$
r=\frac{n \sum X Y-\left(\sum X\right)\left(\sum Y\right)}{\sqrt{n \sum X^{2}-\left(n \sum Y\right)^{2}\left(n \sum Y^{2}-\left(\sum Y\right)^{2}\right)}}
$$

Keterangan :

r: Koefisien korelasi product moment

$\mathrm{n}: \quad J u m l a h$ pengamatan

$\mathrm{x}$ : Skor pertanyaan

y: Total skor pertanyaan 
Uji signifikan dilakukan dengan membandingkan nilai $r$ hitung dengan $\mathrm{r}$ tabel untuk degree of freedom $(\mathrm{df})=$ $\mathrm{n}-2$, dimana $\mathrm{n}$ adalah ukuran sampel. Jika $\mathrm{r}$ hitung $>\mathrm{r}$ tabel dan bernilai positif atau tingkat signifikansi satu ujung $<0,05$ maka butir pertanyaan dianggap valid (Ghozali, 2011:53)

Uji Reliabilitas pada dasarnya adalah sejauh mana hasil suatu pengukuran dapat dipercaya. Jika hasil pengukuran yang dilakukan berulang maka menghasilkan hasil yang relatif sama, pengukuran tersebut dianggap memiliki reliabilitas yang baik (Suliyanto, 2005:42).

Reliabilitas diukur dengan uji statistik Cronbanch Alpha ( $\alpha$ ) (Sekaran, 2006:113) dengan rumus :

Keterangan :

$$
r i=\left[\frac{K}{K-1}\right]\left[\frac{\sum \sigma b^{2}}{\sigma^{2} t}\right]
$$

$\mathrm{Ri}$ : Reliabilitas instrumental

$\mathrm{K}$ : banyaknya butiran pertanyaan

$\sum \sigma b^{2}:$ Jumlah varian butir

$\sigma^{2} \mathrm{t} \quad$ : skor pertanyaan

Jika nilai alpha $>\mathrm{r}$ tabel, berarti kuisioner reliabel

\section{Analisis Regresi Berganda}

Analisis regresi berganda digunakan untuk mengetahui besarnya pengaruh efektivitas iklan pesaing, atribut produk, dan perilaku mencari variasi secara parsial maupun bersamaan terhadap perilaku perpindahan merek produk indomie. Maka persamaan regresinya sebagai berikut ini (Suliyanto,2011:54) :

$$
Y=a+b_{1} X_{1}+b_{2} X_{2}+B_{3} X_{3}+\epsilon
$$

Keterangan :

Y : Perilakuu perpindahan merek
a : Konstanta
b1 : Koefisien regresi X1
b2 : Koefisien regresi X2
b3 : Koefisien regresi X3
$\mathrm{X} 1$ : Efektivitas iklan pesaing
$\mathrm{X} 2$ : Atribut produk
X3 : Perilaku mencari variasi
$\epsilon \quad$ : Nilai residu

Koefisien determinasi

Koefisien determinasi $\left(\mathrm{R}^{2}\right)$ merupakan besarnya kontribusi variabel bebas terhadap variabel tergantungnya. Koefisien ini bertujuan untuk mengukur seberapa jauh kemampuan model dalam menerangkan variabel dependen.

Uji t

Uji $t$ digunakan untuk menunjukan apakah suatu variabel independen secara individual mempengaruhi variabel dependen (Suliyanto, 2011:26)

$$
t=\frac{\beta 1}{\operatorname{se}(\beta 1)}
$$

Keterangan :

$$
\begin{array}{ll}
\mathrm{t} & : \text { Nilai t hitung } \\
\beta 1 & \text { : Koefisien regresi } \\
\operatorname{se}(\beta 1) & : \text { Kesalahan baku koefisien } \\
& \text { regresi }
\end{array}
$$

Dengan derajat kebebasan $(\mathrm{df})=(\mathrm{n}-\mathrm{k}-$ 1) dan tingkat keyakinan $95 \%$ $(\alpha=0,05)$.

Pengujian Asumsi Klasik diperlukan untuk mengetahui apakah model regresi akan dapat dijadikan alat estimasi yang tidak bias. Oleh karena itu, uji asumsi klasik perlu dilakukan. Dalam penelitian ini uji asumsi klasik yang digunakan adalah uji Normalitas, uji Multikolinieritas dan uji Heteroskedastisitas.

\section{Pengujian Hipotesis}


Untuk menguji hipotesis yang dipakai :

Ho: $b_{i} \leq 0$, artinya suatu variabel independen tidak berpengaruh terhadap variabel dependen.

Ha: $b_{i}>0$, artinya suatu variabel independen berpengaruh terhadap variabel dependen.
Dengan kriteria pengujian pada tingkat signifikansi $\alpha=0,05, \mathrm{df}=\mathrm{n}-\mathrm{k}$ ditentukan sebagai berikut:

Ho diterima apabila $-t_{\text {hitung }} \geq$ $-t_{\text {tabel }}$ atau $t_{\text {hitung }} \leq t_{\text {tabel }}$ atau nilai signifikansi $>0,05$. dan $\mathrm{Ha}$ ditolak.

\section{HASIL ANALISIS}

\section{Analisis Regresi Berganda}

\section{Persamaan Regresi}

Tabel 2. Ringkasan Hasil Analisis Regresi Berganda

\begin{tabular}{lllll}
\hline No & Variabel & $\begin{array}{l}\text { Koefisien } \\
\text { Regresi }\end{array}$ & $\mathrm{t}_{\text {hitung }}$ & $\begin{array}{l}\mathrm{t} \text { tabel } \\
\text { (two tilled) }\end{array}$ \\
\hline 1 & Efektivitas Iklan Pesaing & 0,362 & 8,718 & 1,985 \\
2 & (X1) & 0,257 & 7,039 & 1,985 \\
3 & Atribut Produk (X2) & 0,264 & 6,105 & 1,985 \\
& Perilaku Mencari Variasi & & \\
(X3) & & & \\
\hline Konstanta & & & \\
Adjusted $R \quad=0,648$ & & & \\
Square & $=0,834$ & & \\
Fhitung & $=167,208$ & & \\
\hline
\end{tabular}


Berdasarkan tabel 2, dapat dibuat persamaan regresi berganda sebagai berikut :

$$
Y=0,648+0,362 X_{1}+0,257 X_{2}+0,264 X_{3}+e
$$

Konstanta sebesar 0,648 artinya jika variabel efektivitas iklan pesaing, atribut produk, dan perilaku mencari variasi tidak ada perubahan atau konstan, maka perilaku perpindahan merek bernilai 0,648.

Koefisien regresi variabel efektivitas iklan pesaing sebesar 0,362 berarti mempunyai pengaruh positif terhadap perilaku perpindahan merek, atau dapat pula dinyatakan bahwa jika efektivitas iklan pesaing meningkat sebesar satu satuan, maka akan dapat meningkatkan perilaku perpindahan merek sebesar 0,362.

Koefisien regresi variabel atribut produk sebesar 0,257 berarti mempunyai pengaruh positif terhadap perilaku perpindahan merek. Dapat pula dinyatakan bahwa jika atribut produk meningkat sebesar satu satuan, maka
Koefisien regresi variabel perilaku mencari variasi sebesar 0,264 berarti mempunyai pengaruh positif terhadap perilaku perpindahan merek. Dapat dinyatakan pula bahwa jika perilaku mencari variasi meningkat sebesar satu satuan, maka perilaku perpindahan merek akan meningkatkan sebesar 0,264 satuan

Dari persamaan regresi di atas, diperoleh adjusted $\mathrm{R}^{2}$ sebesar 0,834 atau $83,40 \%$. Hal ini berarti variable perilaku perpindahan merek dipengaruhi oleh variasi variable-variabel perubahan efektivitas iklan pesaing, atribut produk, dan perilaku mencari variasi sebesar $83,4 \%$ dan sisanya $16,6 \%$ dipengaruhi variabel lain yang tidak diteliti.

\section{Pengujian Hipotesis}

Pengujian signifikansi pengaruh variabel efektivitas iklan pesaing, atribut produk, dan perilaku mencari variasi terhadap perilaku perpindahan merek secara parsial dilakukan uji-t. Dengan menggunakan tingkat kesalahan

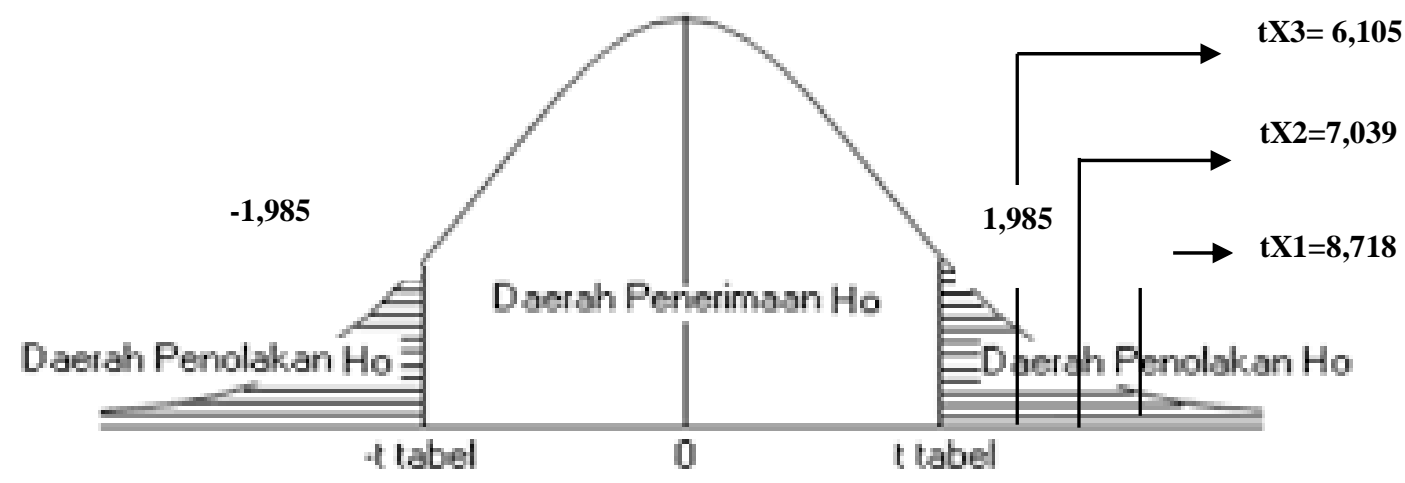

Gambar 2. Kurva Uji t

akan dapat meningkatkan perilaku perpindahan merek sebesar 0,257 satuan $(\alpha)=0,05$ dan degree of freedom $(n-k)$, dimana $\mathrm{n}=100$ dan $\mathrm{k}=4$, maka 
diketahui nilai $\mathrm{t}$ tabel sebesar $\pm 1,985$. Adapun dari output analisis regresi berganda pada table 1 diketahui bahwa nilai $\mathrm{t}$ hitung variabel efektivitas iklan pesaing sebesar 8,718 , nilai $t$ hitung variabel atribut produk sebesar 7,039, dan nilai $t_{\text {hitung }}$ variabel perilaku mencari variasi sebesar 6,105. Berdasarkan uji t tersebut, maka secara grafik dapat dijelaskan seperti Gambar 2.

\section{Hipotesis Pertama}

Berdasarkan analisis regresi berganda diperoleh nilai $t$ hitung variabel efektivitas iklan pesaing lebih besar dari dari nilai $t_{\text {tabel }}$ yaitu $8,718>1,985$. Hasil uji tersebut menunjukan bahwa secara parsial efektivitas iklan pesaing berpengaruh positif terhadap perilaku perpindahan merek. Dengan demikian, maka hipotesis pertama yang menyatakan bahwa efektivitas iklan pesaing berpengaruh terhadap perilaku perpindahan merek diterima.

Dari hasil penelitian juga dapat diketahui bahwa secara keseluruhan efektivitas iklan pesaing lebih dapat menarik perhatian dan mudah diingat, serta mampu membuat konsumen untuk melakukan pembelian dibandingkan dengan produk Indomie. Selain itu kurang adanya promosi yang dilakukan produk Indomie dalam menyampaikan informasi juga menjadi salah satu faktor yang membuat konsumen memilih untuk berpindah merek.

Secara empiris, hasil penelitian ini mendukung penelitian sebelumnya yang dilakukan Arma dan Farida (2011) yang menyimpulkan bahwa semakin tinggi efektivitas iklan pesaing maka semakin tinggi pula perilaku perpindahan merek.
Hipotesis Kedua

Hasil uji statistik Nilai $t$ hitung variabel atribut produk lebih besar dari dari nilai $t$ tabel yaitu 7,039>1,985. Hal tersebut menunjukan bahwa secara parsial atribut produk berpengaruh positif terhadap perilaku perpindahan merek. Dengan demikian, maka hipotesis kedua yang menyatakan bahwa atribut produk berpengaruh terhadap perilaku perpindahan merek diterima.

Dari hasil penelitian juga dapat diketahui bahwa sebagian besar responden menganggap atribut produk dari Indomie dirasa tidak lebih baik dibandingkan dengan atribut produk merek mie instan lain baik secara variasi, kualitas dan juga tampilan. Kurangnya variasi dan kualitas yang dianggap belum dapat memenuhi kebutuhan konsumen serta tampilan yang dianggap kurang menarik menjadi salah satu faktor konsumen lebih cenderung melakukan perilaku perpindahan merek.

Hasil penelitian ini konsisten dengan hasil penelitian sebelumnya yang dilakukan Sofiana dan Budiadi (2014) yang menyatakan bahwa atribut produk berpengaruh secara signifikan terhadap perilaku perpindahan merek.

\section{Hipotesis Ketiga}

Pada pengujian hipotesis ketiga diperoleh Nilai $t$ hitung variabel perilaku mencari variasi lebih besar dari nilai $t_{\text {tabel }}$ yaitu 6,105 > 1,985. Hasil uji tersebut menunjukan bahwa secara parsial perilaku mencari variasi berpengaruh positif terhadap perilaku perpindahan merek. Sehingga hipotesis ketiga yang menyatakan bahwa perilaku mencari variasi berpengaruh terhadap perilaku perpindahan merek diterima. 
Dari penelitian ini dapat diketahui bahwa sebagian besar responden merasa bosan dan juga tertarik untuk mencoba hal baru dalam mengkonsumsi produk mie instan lain serta rasa ingin tahu akan beberapa produk lain menjadi faktor yang mempengaruhi perpindahan merek. Banyaknya merek mie instan yang masuk dipasaran juga membuat konsumen lebih cenderung melakukan perilaku perpindahan merek dari produk Indomie.

Secara empiris, hasil penelitian ini mendukung penelitian sebelumnya yang dilakukan oleh Arma dan Farida (2011) dan penelitian yang dilakukan oleh Sofiana dan Budiadi (2014) yang menunjukan bahwa perilaku mencari variasi berpengaruh secara signifikan terhadap perilaku perpindahan merek.

\section{KESIMPULAN DAN IMPLIKASI}

\section{Kesimpulan}

a. Efektivitas iklan pesaing berpengaruh positif terhadap perilaku perpindahan merek dari produk Indomie. Artinya semakin efektif iklan yang dilakukan oleh pesaing maka semakin tinggi pula perilaku perpindahan merek dari produk Indomie yang dilakukan oleh konsumen.

b. Atribut produk berpengaruh positif terhadap perilaku perpindahan merek. Artinya semakin rendahnya atribut produk dari Indomie maka semakin tinggi pula perilaku perpindahan merek yang akan dilakukan oleh konsumen.

c. Perilaku mencari variasi berpengaruh positif terhadap perilaku perpindahan merek dari produk Indomie. Artinya semakin tinggi perilaku mencari variasi yang dilakukan konsumen maka akan semakin tinggi pula perilaku perpindahan merek yang dapat dilakukan oleh konsumen.

\section{Implikasi Manajerial}

Untuk mengurangi perilaku perpindahan merek yang dilakukan konsumen, pihak manajemen perusahan perlu memprioritaskan berbagai kebijakan yang terkait dengan efektivitas iklan, atribut produk, dan perilaku mencari variasi. Upaya yang dapat dilakukan diantaranya adalah:

a. Pihak Indomie sebaiknya melakukan riset terkait iklan yang dilakukan, apakah sudah efektif untuk dapat menarik perhatian dan iklan yang disampaikan mudah diingat sehingga mampu membuat konsumen bertindak melakukan pembelian produk Indomie dengan dapat mengkomunikasikan keuntungan yang spesifik. Seperti peningkatan frekuensi pengiklanan agar menumbuhkan kesadaran konsumen dan penggunaan endorse yang menarik sehingga mampu menarik perhatian konsumen.

b. Untuk memperkuat atribut produk yang ditawarkan sebaiknya pihak Indomie melakukan riset dan pengembangan produk baru dengan berbagai macam variasi seperti variasi rasa dan juga menambah kualitas akan mie instan yang diproduksi untuk meningkatkan nilai tambah bagi konsumen.

c. Melakukan antisipasi pada perubahan preferensi yang dilakukan konsumen dengan terus melakukan inovasi dalam memproduksi mie instan baik pada segi produk maupun harga yang 
terjangkau agar konsumen tidak cepat merasa bosan dan juga konsumen dapat merasa puas dengan produk yang ditawarkan.

\section{Implikasi Teoritis}

Untuk penelitian selanjutnya disarankan menambah variabel independen lain yang diindikasikan kuat mempengaruhi perilaku perpindahan merek seperti variabel harga, ketersediaan produk, dan ketidakpuasan. Selain itu juga perlu mengembangkan model penelitian ini melalui pengujian pengaruh tidak langsung (inderect effect) dengan menambahkan variabel moderasi maupun mediasi.

\section{DAFTAR PUSTAKA}

Arma dan Farida. 2011. Analisis Pengaruh Efektivitas Iklan Pesaing dan Perilaku Mencari Variasi Terhadap Perilaku Perpindahan Merek Pada Konsumen Teh Botol Sosro. Penerbit Universitas Diponegoro. Semarang.

Ghozali, Imam. 2011 . Aplikasi Analisis Multivariate Dengan Program IBM SPSS 19 (edisi kelima). Semarang: Universitas Diponegoro.

ICN. 2009. Laporan Market IntelligenceIndustri Mie Instan Bersaing Ketat. http://www.datacon.co.id/MieInsta nl-2009.html. 20 November 2015 (21:52).

Sekaran, Uma. 2006. Metodologi Penelitian untuk Bisnis. Edisi 4, Buku 1. Salemba Empat. Jakarta.
Simamora, Bilson. 2007. Panduan Riset Perilaku Konsumen. PT. Gramedia Pustaka Utama. Jakarta.

Sofiana P, Meilisa dan Budiadi, S. 2014. Pengaruh Atribut Produk dan Variety Seeking Terhadap Brand Switching. Universitas Surabaya. Surabaya.

Suliyanto . 2005. Analisis Data Dalam Aplikasi Pemasaran. Bogor: Penerbit Ghalia Indonesia.

.2011. Ekonometrrika Terapan: Teori \& Aplikasi dengan SPSS. Andi Offset. Yogyakarta.

WINA. 2015. Expanding Market Global Demands For Instan Noodless. https://instantnoodles.org/noodles lexpanding-market.html. 20 November 2015 (21:59) 